\title{
Research on Foreign Exchange Risk Management under the Background of RMB Internationalization
}

\author{
Lan Dong ${ }^{1, a}$ \\ ${ }^{1}$ School of Economics and Management, Nanjing University of Science and Technology, Nanjing \\ 210094, China \\ a1561186218@qq.com
}

Keywords: RMB internationalization; Foreign exchange risk; Risk Management

\begin{abstract}
With the development of international trade and the progress of the RMB internationalization process, the exchange rate fluctuation and exchange rate elasticity of the RMB increased, which caused the foreign exchange exposure of our enterprises to further increase. The Foreign exchange risk not only affect corporate profits through product prices, raw material prices and labor prices, but also affect the competitiveness of Chinese enterprises in the international market. Therefore, how to manage foreign exchange risk is of great significance for Chinese enterprises in international trade.
\end{abstract}

\section{Introduction}

In 2005, China started to implement a managed floating exchange rate system based on market supply and demand and adjusted it according to a basket of currencies. May 21, 2007, the central bank announced the interbank spot foreign exchange market, the dollar / dollar trade price range of $0.3 \%$ to $0.5 \%$. As of April 10, 2008, the central parity rate of RMB against the U.S. dollar broke through 700 points for the first time. From 2005 to 2008, the RMB appreciation rate up to 19\%. The global financial crisis in 2008 suspended the trend of appreciation of the RMB and started to peg to the U.S. dollar again. After the financial crisis subsided, China's exchange rate policy remained tightened until June 19, 2010, when the People's Bank of China restarts the RMB exchange rate reform. On April 14, 2012, the People's Bank of China decided to raise the floating exchange rate of RMB against the US dollar in the inter-bank spot foreign exchange market to 1\%. On March 15, 2014, the People's Bank of China expanded the exchange rate of RMB against the U.S. dollar for the fourth time and expanded from March 17, 2014 to 2\%.

As a developing economic power, China's economy has been integrated into the international economic system. The scale of foreign exchange reserves has been on an upward trend since 2008, reaching 384.3 billion U.S. dollars in 2014. Foreign exchange reserves have declined in recent two years, but the total amount is still large. In addition, huge trade surpluses bring more and more foreign exchange risks to enterprises. On the other hand, processing trade is a major form of trade in China. Its technical content, innovation and added value are relatively low. Therefore, enterprises are greatly affected by external economic fluctuations.

Foreign exchange risk is divided into transaction risk, accounting risk and economic risk three. Rodriguez (1974) argues that foreign exchange risk is a gain or loss caused by a change in the value of a foreign currency. Adler and Dumas (1984) consider foreign exchange risk as the effect of exchange rate changes on firm cash flow and firm value. Euteman et al. (1989) consider that foreign exchange risk refers to the change of exchange rate that changes the company's profitability, net cash flow and market value potential, which will have a significant impact on the production and operation of the enterprise. The main factors affecting foreign exchange risk are asset exposures, asset exposure periods and exchange rate fluctuations. Since exchange rate fluctuations are the only uncertain factors, they are considered the most important factor. This paper analyzes the foreign exchange risks brought by the fluctuation of RMB exchange rate in the process of people's internationalization and puts forward some measures to avoid the foreign exchange risk. 


\section{Analysis of the fluctuation of RMB exchange rate}

Before China's exchange rate reform in July 2005, China has been implementing a foreign exchange rate policy that is closely linked to the dollar, the RMB exchange rate of RMB exchange rate remained at 8.2765 RMB to 1 dollar level. After the People's Bank of China changed the original foreign exchange management, began to implement the market supply and demand, with reference to a basket of currencies to adjust the floating exchange rate system, which is China's international trade to adapt to the inevitable result. This new exchange rate system changed the original pattern of changes in the RMB exchange rate, so that the RMB exchange rate changes closer to the market, more objectively reflect the exchange rate market supply and demand changes.

From 2005 to 2013, the historical trend of the RMB exchange rate, as shown in Figure1, by the domestic and international political and economic development, the RMB exchange rate against the US dollar is mainly to maintain a strong trend of appreciation, during this time, due to the sub-prime mortgage crisis occurred in the United States, and spread to the Global, in order to protect the RMB price in the international money market is relatively stable, but also to prevent from the US sub-prime mortgage crisis caused more profound trauma to China, the Central Bank in 2008 fixed the RMB exchange rate against the dollar, making the RMB against the dollar at a relatively stable price and stopping the appreciation of the RMB, also protecting the relative price of the RMB exchange rate. After 2010, the RMB continued to appreciate against the dollar, while by the end of 2013 the RMB against the dollar rose to 6.10 or so, brush a record high.

In 2014, the exchange rate of RMB against the US dollar changed the trend of the continued appreciation of the RMB, showing more two-way volatility. From the 2014 full year of the Yuan against the US dollar exchange rate on the $\mathrm{K}$ line Figure 2 can be seen that at the beginning of the year, the RMB exchange rate against the US dollar was near 6.04, then began to fall rapidly, has been down to 6.27 positions at the end of April. In the next six months the RMB exchange rate continued to raise, by the end of October closed at around 6.11, in the last two months of 2014 the RMB exchange rate rose sharply of $1.5 \%$. At the beginning of 2015, the exchange rate of the RMB against the US dollar began to decline again. Since 2015, the trend of RMB against the dollar has become more and more complex, which further shows that under the current exchange rate system, the RMB exchange rate volatility gradually increased, two-way volatility is more and more frequent, and the trend of RMB marketization is more obvious.

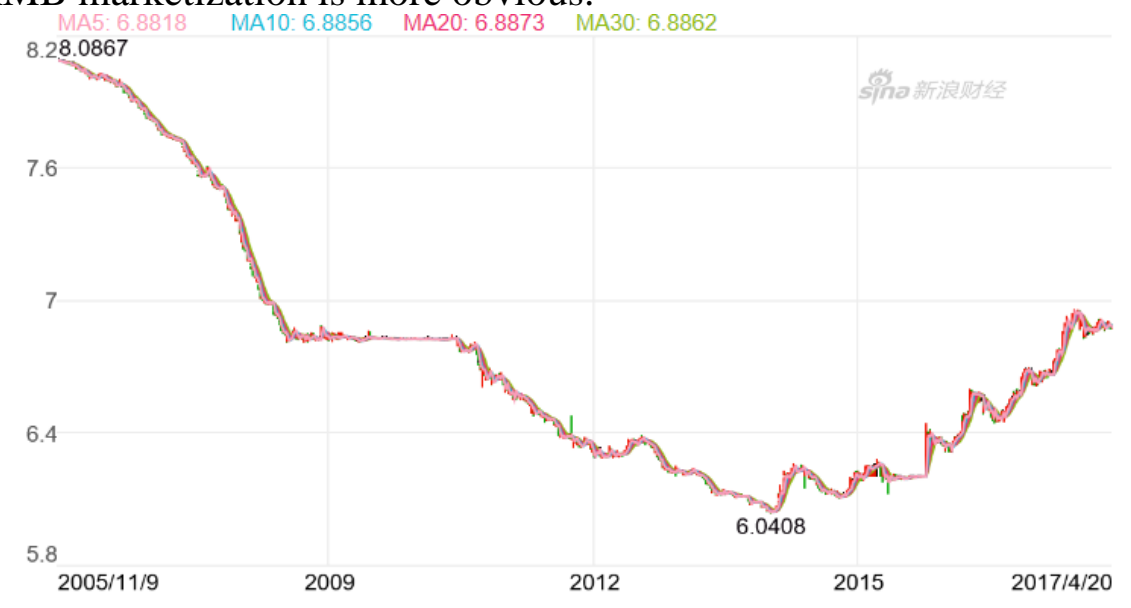

Figure 1 Figures for the US dollar against the RMB since 2005 


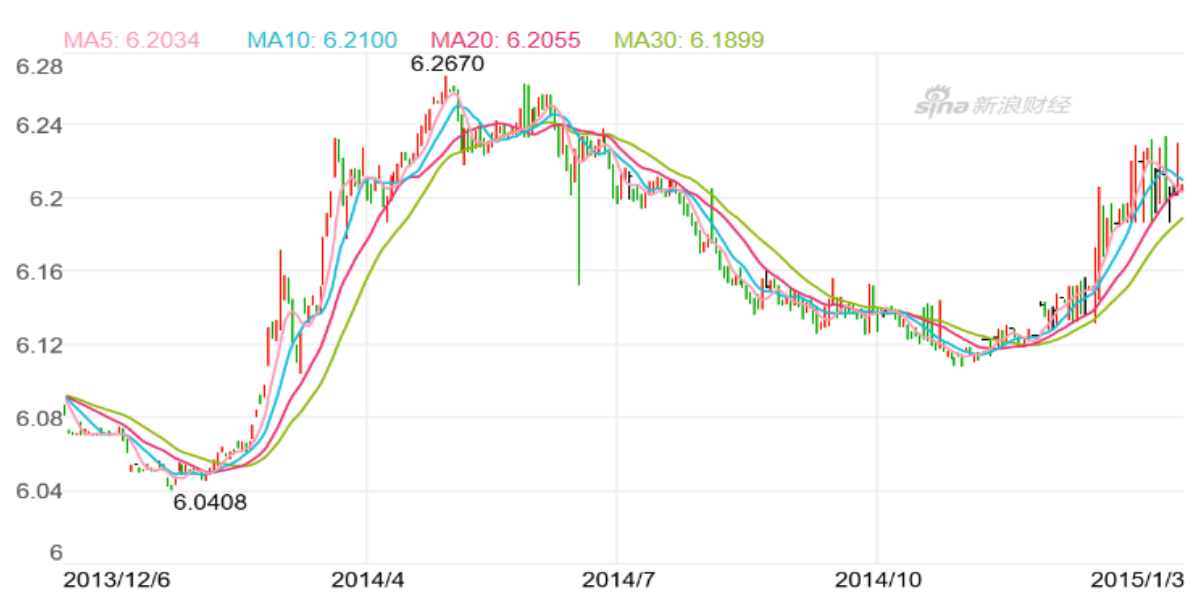

Figure 2 Trends of the US dollar against the RMB exchange rate in 2014

\section{Foreign Exchange Risk Management Measures}

Floating exchange rate system has increased the flexibility of the RMB exchange rate, exacerbated the exchange rate fluctuations, foreign trade enterprises are facing higher exchange rate risk. Faced with the uncertainty of the exchange rate market, Chinese enterprises should continuously enhance the core competitiveness of their existing businesses, and offset the foreign exchange risk through diversification to maximize the benefits of the Company. In addition, only by continuously improving the innovation capability of enterprises and increasing the added value of products can we avoid the losses caused by the fluctuation of competitive exchange rates with industry prices. However, the improvement of innovation capability is not easy and requires long-term investment and accumulation. In addition, enterprises should also establish a rigorous foreign exchange risk examination and authorization management system, the formation of foreign exchange risk management system, in order to more effectively avoid foreign exchange risk.

\section{References}

[1]Karmakar A K, Mukherjee S. In Looking into the Foreign Exchange Risk Management [M]// Risk Management, Strategic Thinking and Leadership in the Financial Services Industry. Springer International Publishing, 2017.

[2]Steven M. Foreign Exchange Risk Management [J]. Long Range Planning, 2015, 12(3):22-27.

[3]Zhou A, Zhang J, Qin M, et al. RMB Internationalization: A Review [J]. Journal of Chengdu University of Technology, 2014.

[4]Jie X U. Discussion about RMB Internationalization [J]. Journal of Guangxi Economic Management Cadre College, 2012.

[5]Strategy of RMB Internationalization Development [J]. 2012. 